\title{
BUSINESS STRATEGY FORMULATION BY SHAREHOLDERS AND COMPANY MANAGEMENT USING ANALYTICAL NETWORK PROCESS (ANP)
}

\author{
Faizal $^{1}$; Achsanul Qosasi²; Antonius W. Sumarlin ${ }^{3}$; Erwin Permana ${ }^{4}$; \\ Gatot Hendro Prakosa ${ }^{5}$; Indriana ${ }^{6}$; Glory Aguzman ${ }^{7}$ \\ 1,2,3 Magister Manajemen Sekolah Pascasarjana, Universitas Pancasila \\ Jalan Raya Lenteng Agung, RT. 1/RW. 3, Srengseng Sawah, Jagakarsa, Jakarta Selatan, DKI Jakarta 12640 \\ 4,5,6,7Binus Entrepreneurship Center, Bina Nusantara University \\ Jln. K.H. Syahdan No 9, Jakarta Barat, DKI Jakarta, 11480, Indonesia \\ 1Faizal.helmi1973@gmail.com; ${ }^{2}$ achsanul@indosat.net.id; ${ }^{3}$ aw.sumarlin@gmail.com; \\ 4erwin.permana@binus.ac.id; ${ }^{5}$ gprakosa@binus.edu; ${ }^{6}$ indriana@binus.edu; ${ }^{7}$ gguzman@binus.edu
}

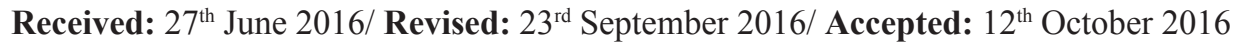

How to Cite: Faizal, Qosasi, A., Sumarlin, A. W., Permana, E., Prakosa, G. H., Indriana, \& Aguzman, G. (2016). Business Strategy Formulation by Shareholders and Company Management Using Analytical Network Process (ANP). Binus Business Review, 7(3), 297-305. http://dx.doi.org/10.21512/bbr.v7i3.1494

\begin{abstract}
This research aimed to identify the business strategy formulation by the shareholders and the management of the company. Ten companies were selected to be the objects of this research. Those companies were the information technology, telecommunication, printing, mining, construction and chemical companies in Indonesia. The research was conducted by using the Analytical Network Process (ANP) and considering the chosen respondents as the decision makers (experts) of those companies. The respondents were chosen by using the non-probabilitty sampling method. The result shows that the roles of the company managements are considered $m$ ore influental $(0,57143)$ than the roles of the shareholders $(0,28571)$. From the output of stakeholder's condition, the beststratified priority strategies are differentiation $(0,600515)$, cost of leadership $(0,230754)$ and focus $(0,168731)$.
\end{abstract}

Keywords: business strategy, strategy formulation, shareholders, company management, Analytical Network Process, ANP

\section{INTRODUCTION}

The objective of an establishment of a company is to gain the profit after they have made the investment. According to Edelman et al. (2010), new entrepreneurs were motivated to create a new venture in term to get some outcomes. To pursue the profit, companies are forced to formulate and implement the effective and efficient business strategy to win the competition. Wheelen and Hunger (2011) stated that to be successful in the long-run of the company business; companies had to adapt to the market and satisfy the changing market by using the perfect strategy.

The operational activities of the company will require the roles and functions of shareholders and the company management which consist of commissioners, management, and managers. The shareholders are the persons or legal entities that legally have one or more share in the company.

Corporation management explains a set of relationship between corporate management, boards of commissioners, shareholders, and its stakeholders. The corporate management is a process when the commissioners and the auditor set their responsibilities to the shareholders and stakeholders. The governance of the corporation can improve the confidence of the shareholders and stakeholders on the fair return on their investment.

Shlefier and Vishny (1997) in Price et al. (2011) said that corporate governance systems were designed to make sure that the investors gained the fair return on their investment. Stronger governance systems lead 
to more efficient of capital resources that will boost the economic growth as well.

Ntim et al. (2012) stated that the disclosing corporate governance practices related to the improvement of the market value of the corporation. The good corporate governance combines the law, rules and voluntary practices of the private sectors that give the corporate the chances to attract investment, work efficiently, make profits, fulfill the legal liabilities, and fulfill the social expectation.

Siregar and Bachtiar (2010) explained that most of the definition of the board in the developed countries were the one-tier board system, which was different with the board system adopted by Indonesia, the two-tier board system. The two-tier board system consists of two boards, boards of commissioners and boards of directors.

The existence of the broadened boards inside the good corporate governance mechanism represents the accountability principles and the independency of the decision makers. The good decision would lead the corporate to gain a high level of profits. Theoritically, the existence of broadened boards improves the value of the stakeholders.

Inequality access of information can be prevented by giving the signal from one side that reveals the relevant information to the other sides. The receiver would interpret the received signal by offering the higher or lower price. These would impact the diversity of the boards. This is a signal that the corporate applies the good corporate governance, especially for the accountability and the independecy of the decision-maker. This is the good news for the investors which improves the value of the corporate.

Millet-Reyes and Zhao (2010) stated that the large boards might have some communication problems, which became some negative impacts on the performance of the corporate. Cheng (2008) in Millet-Reyes and Zhao (2010) showed the evidence that the larger boards lead the corporate to have lower performance since it would be hard to reach consensus on the boards.

Bai (2013) described that the conflicts between managers and shareholders could be mitigated by the boards of directors. Jensen in Bai (2013) stated that the large boards were less effective than the small boards, regarding monitoring.

In terms of formulating the business strategy, the corporation should use its competitive advantage. Porter (1985) as cited in Wheelen and Hunger (2011) said that there were three kinds of strategies to help the organization to gain the competitive advantages. Those are Cost Leadership, Differentiation, and Cost Focus. The competitive advantages determined by these three strategies above would help the corporation maintain its position in the market.

This research would discuss the impact of corporate shareholders and management to the formulated and implemented business strategies. Ten companies have been chosen as the research objects. Those companies can be seen in Table 1 .
Table 1 Institution List

\begin{tabular}{cl}
\hline No. & \multicolumn{1}{c}{ Institutions/Companies } \\
\hline 1 & PT. Argenta Adhiloka Pratama \\
2 & PT. Argenta Parakrama Artha \\
3 & PT. Asia Pasifik Fiber Tbk \\
4 & PT. Atlas Resources, Tbk \\
5 & PT. Galia Indonesia Printing \\
6 & PT. Jagarti Sarana Telekomunikasi \\
7 & PT. Laplasindo Pratama \\
8 & PT. Sarana Reswara Abadi \\
9 & PT. Satkomindo Mediyasa \\
10 & PT. Suryajaya Teknotama \\
\hline
\end{tabular}

Those companies are nongovernment-owned companies with different kind of business and business strategies. The performance comparison of those companies would be a very useful research to determine the role of the corporate shareholders and managements to the succeed of the business strategy.

David (2011) stated that strategy is way to achieve the long-run objective. The business strategy could be formed as geographical expansion, diversification, acquisition, product development, market penetration, employee rationalization, liquidation and joint venture.

Nickols (2000) described that strategy is the perspective, position, plan and pattern. It is the bridge between the policy or high-order goals in one side, and tactics and actions on the other side. The strategy is a term that refers to a combination of thoughts, ideas, insight, experiences, goals, expertise, memories, perception, and expectations that give the general guidelines for making specific actions in term of pursuing the goals. The strategy refers to a general plan of action to achieve goals and objective of a company or an organization. Furthermore, the strategy might be formulated for broad, long-term, corporate goals and objectives, for more specific business unit goals and objectives, or for a functional unit, even the smallest one. Based on that statement, it is rephrased that the strategy is about (1) the direction of the business in long-term, (2) the kind of business environment (markets) that they wanted to penetrate and the kind of activities that are normally done in that environment, (3) the better business performance compared to the existing competitors in that business environment, (4) the resources to support the business competition, (5) the kind of external factors that might influence the competitive ability in the business environment, and (6) the kind of value and expectations that are expected by the stakeholders.

Strategy formulation is the process of developing the steps to build the vision and mission of the organization, to set the strategic and financial objectives of the company, and to develop the strategy to achieve the objectives in term of providing the best customer value. Wheelen and Hunger (2011) explained that strategy formulation was a development of long-range plans for the effective management of environmental 
opportunities and threats, and consideration of the strength and the weakness (SWOT).

According to Porter (1990), competitive advantage could only be obtained from one of two sources, from the cost leadership - the advantage to set the low cost or the advantage to become the different organization among the competitors (differentiation). The second factor of this approach is the competitive scope where the organization competes against each other in the broad or narrow market. The combination of both factors forms the basic of the generic competitive strategy of Porter, which are cost leadership, differentiation, and focus.

At the beginning of its existence, balanced scorecard has been considered as a system of scoring management and controlling that can precisely, comprehensively and immediately give the information to the manager about the business performance. It was introduced by Kaplan and Norton (1996), it was defined as ".... a set of measure that gives top managers a fast but comprehensive view of the business, includes financial measures that tell the results of actions already taken, complements the financial measures with operational measures on customer satisfaction, internal process and the organization's innovation and improvements activities - operational measures that are the drivers of future financial performance."

It is more than just a tactical and operational measurement system. It is a management system to arrange the implementation of the strategy, and measure the performance by focusing on financial perspective and communicating the vision, strategy and performance expectation from the stakeholders. An innovative company uses balanced scorecard as a strategic management system to manage the longrange strategy and to obtain a management process.

Kaplan and Norton (1996) explained that there were four perspectives of balanced scorecard, which were financial perspective, customer perspective, internal business process perspective, and learning and growth perspective. Moreover, David (2011) stated that management was divided into several main actions which were planning, organizing, motivating, staff placement, and controlling inside of an organization.

Management is used in all kinds of actions whether it is professional or nonprofessional actions, governmental or private organization. Thus, management can be classified into two ways, the level of the organization and the scope of the actions that will be done.

\section{METHODS}

Data is collected from the shareholders and experts. Structured in-depth interview method is used to collect the data. The participants are the shareholders and experts that have been confirmed earlier.

The participants are selected by using the nonprobability sampling by choosing from the experts, and the next will be the stakeholders. In the next stage, the chosen participants are selected by using the purposive sampling method. Table 2 shows the participants of the interview in this research.

Table 2 Stakeholders and Experts Structured In-depth Interview

\begin{tabular}{|c|c|c|c|}
\hline No. & Name & Institution/Company & Position \\
\hline 1 & $\begin{array}{l}\text { Ir. Sari Lestari } \\
\text { Darmawan }\end{array}$ & $\begin{array}{l}\text { PT. Argenta Adhiloka } \\
\text { Pratama }\end{array}$ & $\begin{array}{l}\text { Director and } \\
\text { Shareholder }\end{array}$ \\
\hline 2 & Ferry Yantho, S. Kom & $\begin{array}{l}\text { PT. Argenta Parakrama } \\
\text { Artha }\end{array}$ & $\begin{array}{l}\text { Commissioner } \\
\text { and shareholder }\end{array}$ \\
\hline 3 & $\begin{array}{l}\text { Dr. Antonius } \\
\text { Widyatma Sumarlin, } \\
\text { B.A., M.A. }\end{array}$ & $\begin{array}{l}\text { PT. Asia Pasifik Fiber } \\
\text { Tbk }\end{array}$ & $\begin{array}{l}\text { Independent } \\
\text { Director }\end{array}$ \\
\hline 4 & $\begin{array}{l}\text { Joko Kus Sulisyoko, } \\
\text { S.T. }\end{array}$ & $\begin{array}{l}\text { PT. Atlas Resources, } \\
\text { Tbk }\end{array}$ & $\begin{array}{l}\text { Director and } \\
\text { Shareholder }\end{array}$ \\
\hline 5 & Yasmin Syahrul, S.E. & $\begin{array}{l}\text { PT. Galia Indonesia } \\
\text { Printing }\end{array}$ & Director \\
\hline 6 & I Ketut Suardiasa, S.E. & $\begin{array}{l}\text { PT. Jagarti Sarana } \\
\text { Telekomunikasi }\end{array}$ & Director \\
\hline 7 & $\begin{array}{l}\text { Hansel Sosrosaputro, } \\
\text { B.Eng. }\end{array}$ & $\begin{array}{l}\text { PT. Laplasindo } \\
\text { Pratama }\end{array}$ & $\begin{array}{l}\text { Director and } \\
\text { Shareholder }\end{array}$ \\
\hline 8 & $\begin{array}{l}\text { M.M Asqar, S.E., } \\
\text { M.M. }\end{array}$ & $\begin{array}{l}\text { PT. Sarana Reswara } \\
\text { Abadi }\end{array}$ & Director \\
\hline 9 & $\begin{array}{l}\text { Rayendra Yusron, S. } \\
\text { Kom., M.M. }\end{array}$ & $\begin{array}{l}\text { PT. Satkomindo } \\
\text { Mediyasa }\end{array}$ & Director \\
\hline 10 & Ir. Ali Soegiharto & $\begin{array}{l}\text { PT. Suryajaya } \\
\text { Teknotama }\end{array}$ & $\begin{array}{l}\text { Director and } \\
\text { Shareholder }\end{array}$ \\
\hline
\end{tabular}

Researchers conduct direct interviews by asking some questions directly to the participants. The interview is separated into two categories. First, the unstructured interview which is used by using the interview guide that consists of the guidelines of the interview. This is done in term of making sure that the interview will be done as it is set in the objective.

Second, the structured interview was done by using the questionnaires as the first step to fill the priority of the Analytical Network Process. If there were any dissenting judgment from the expert participants on some certain priorities, the geometric mean procedure would be done (Saaty, 2008).

This research was done by using the quantitative and qualitative method using the descriptive technique. It was started by using the ANP priority theory and analysis, and by generalizing the findings of the research so it would be able to be used to predict the similar situations to other populations and explain the causality relation between studied clusters and variables.

Analytic Network Processor (ANP) is a decision-making tool that is developed from the Analytic Hierarchy Process (AHP) approach. AHP 
and ANP are developed by Prof. Dr. Thomas L. Saaty, a professor at Pittsburg University, United States. According to Saaty (2003), ANP was a relative measurement general theory that could be used to reduce the composite priority ratio of an individual ratio scale that described the relative measurement to the elements that influenced one to another as control criteria.
Azis (2003) defined ANP as an application of the mathematic theory that allowed someone to treat the dependency and to give feedback systematically so it could capture and combine the tangible and intangible factors.

Based on the literature review and the confirmation of the experts in this research, the researchers design an ANP network model as it is shown in Figure 1.

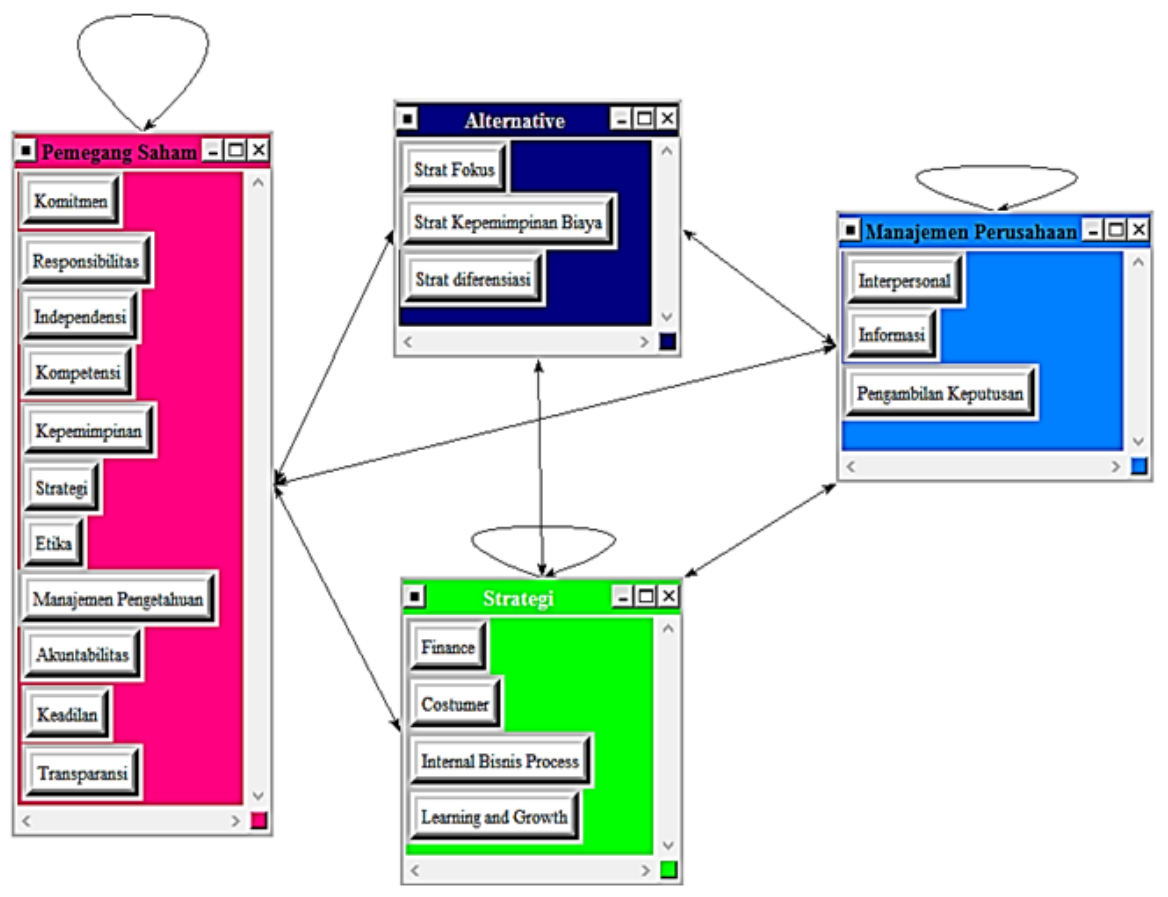

Figure 1 ANP Network

\begin{tabular}{|c|c|c|c|c|}
\hline \multicolumn{5}{|c|}{ Here are the priorities. } \\
\hline \multirow{2}{*}{\begin{tabular}{|l|} 
Icon \\
No kon \\
\end{tabular}} & \multirow{2}{*}{$\begin{array}{c}\text { Name } \\
\text { Strat diferensiasi }\end{array}$} & \multicolumn{3}{|c|}{$\longdiv { \text { Normalized by Cluster [Limiting } }$} \\
\hline & & 「 & $\overline{0.60052}$ & $\longdiv { 0 . 1 6 3 7 1 8 }$ \\
\hline No Icon & Strat Fokus & $\Gamma$ & 0.16873 & 0.046001 \\
\hline No kon & Strat Kepemimpinan Biaya & 「 & 0.23075 & $\longdiv { 0 . 0 6 2 9 1 0 }$ \\
\hline No kon & Informasi & Г & 0.23585 & 0.064300 \\
\hline No kon & Interpersonal & Г & 0.33728 & 0.091952 \\
\hline No kon & Pengambilan Keputusan & $\Gamma$ & 0.42687 & 0.116377 \\
\hline No kon & Akuntobilitas & Г & 0.18755 & 0.033513 \\
\hline No kon & Etika & Г & 0.04417 & 0.007892 \\
\hline No kon & Independensi & Г & 0.08373 & $\longdiv { 0 . 0 1 4 9 6 2 }$ \\
\hline No kon & Keadilan & 厂 & 0.06156 & 0.011001 \\
\hline No kon & Kepemimpinan & Г & 0.06929 & 0.012382 \\
\hline No kon & Komitmen & Г & 0.19610 & 0.035042 \\
\hline No kon & Kompetensi & 「 & 0.08239 & 0.014723 \\
\hline No kon & Manajemen Pengetahuan & 「 & 0.04607 & $\longdiv { 0 . 0 0 8 2 3 2 }$ \\
\hline No Icon & Responsibilitas & Г & 0.08459 & 0.015115 \\
\hline No kon & Strategi & Г & 0.04963 & 0.008690 \\
\hline No kon & Transparansi & Г & 0.09592 & 0.017141 \\
\hline No kon & Costumer & 厂 & 0.31734 & 0.087602 \\
\hline No kon & Finance & Г & 0.32680 & $\longdiv { 0 . 0 9 0 2 1 4 }$ \\
\hline No kon & Internal Bisnis Process & I & 0.17172 & 0.047403 \\
\hline No lcon & Leaming and Growth & T & 0.18414 & 0.050331 \\
\hline
\end{tabular}

Figure 2 Output of Super Decisions Software 


\section{RESULTS AND DISCUSSIONS}

The synthesis of pairwise comparisons is obtained through the data processing done one by one by each participant. Using the super decision software, the data is processed to have the supermatrix. This supermatrix is showing the order of the most important clusters priorities from the factors that are related to the business strategy formulated by the shareholders and company's management. The order of the strategy priority and the ANP alternative strategy output would be shown in Figure 2.

In Figure 2, the output of the Super Decision software shows the entire output, which is the sum of the whole clusters so it would generate the 21 strategy priorities. The ANP output is not only generating the whole prorities, but it is also generating two values which are normalized by cluster and the limiting value. The normalized by cluster value is the priority value of every single cluster which is worth as much as 1 or 100 percent when it is summed up within one cluster. Limiting value, on the other hand, is the priority value on all of the node priorities (attributes) of the problem and alternative solution between the clusters.

The result of the ANP output was being reexamined again to define the priority based on the Limiting Value weight. Based on the output, it was known that the main strategy that became the priority from the total strategy was the cost differentiation strategy $(0,163718)$, followed by the decision-making $(0,116377)$. The priority of the strategies is described in Table 3.

The researchers could define the management hierarchy for the whole priority steps by dividing it all with the three hierarchy. Table 4 explain about the solutive act of the strategic hierarchy and implementer management matrix.

There are three levels of business or operational strategy decision-making inside of business strategy formulation process by shareholders and management of the company. Thus, from the total of 21 priorities, each hierarchy has seven priorities. The first seven priorities are categorized in the strategic steps, the second seven were in the tactical steps, and the last seven were in the operational category.

The strategic steps are the long range decision of the company to reach the business objectives. In this term, there are several steps that have been considered as the priority. Those steps are (1) Differentiation Strategy, (2) Decision-making, (3) Interpersonal, (4) Finance, (5) Costumer, (6) Information, and (7) Cost Leadership Strategy.

The tactical steps are the expansion of the strategic steps that are considered to be more of short term. The short-term steps are created to be implemented in almost all lines of the business organization. The prioritized steps to be developed in all lines/department of the company would be (1) learning and growth, (2) internal business process, (3) focus, (4) commitment, (5) accountability, (6) transparency, (7) responsibility.
The operational steps were focused on the business operation to maximize the market potential and to be able to adapt to the short term changes by focusing on: (1) independency, (2) human resource improvement, (3) professional leadership, (4) fairness to all stakeholders, (5) always refers to the strategy, (5) systematic knowledge management, and (6) playing the business based on ethic. These seven steps of operational's existence would be useful to cover all business problems so the business strategy of the company would be achieved.

The analysis of the role of the shareholders and the management of the company to the business strategy formulation will require the analysis of the pairwise comparison of the clusters especially the management of the company cluster, shareholders, and strategy.

Soon after the opinions of the expert were being inputted to the ANP software, it is revealed that the management of the company has bigger roles $(0,57143)$, compared to the shareholders $(0,28571)$. The result of the ANP Output between clusters based on the processing in the Super Decisions software is shown in Figure 3.

Table 3 Business Strategy Priority by the Shareholders and the Management of the Company

\begin{tabular}{|c|c|c|c|}
\hline Priority & Node & $\begin{array}{l}\text { Normalized } \\
\text { by cluter }\end{array}$ & Limiting \\
\hline (1) & (2) & (3) & (4) \\
\hline 1 & $\begin{array}{l}\text { Differentiation } \\
\text { Strategy }\end{array}$ & 0,60052 & 0,163718 \\
\hline 2 & Decision-making & 0,42687 & 0,116377 \\
\hline 3 & Interpersonal & 0,33728 & 0,091952 \\
\hline 4 & Finance & 0,32680 & 0,090214 \\
\hline 5 & Costumer & 0,31734 & 0,087602 \\
\hline 6 & Information & 0,23585 & 0,064300 \\
\hline 7 & $\begin{array}{l}\text { Cost Leadership } \\
\text { Strategy }\end{array}$ & 0,23075 & 0,062910 \\
\hline 8 & $\begin{array}{l}\text { Learning and } \\
\text { Growth }\end{array}$ & 0,18414 & 0,050831 \\
\hline 9 & $\begin{array}{l}\text { Internal Business } \\
\text { Process }\end{array}$ & 0,17172 & 0,047403 \\
\hline 10 & Focus Strategy & 0,16873 & 0,046001 \\
\hline 11 & Commitment & 0,19610 & 0,035042 \\
\hline 12 & Accountability & 0,18755 & 0,033513 \\
\hline 13 & Transparency & 0,09592 & 0,017141 \\
\hline 14 & Responsibility & 0,08459 & 0,015115 \\
\hline 15 & Independency & 0,08373 & 0,014962 \\
\hline 16 & Competency & 0,08239 & 0,014723 \\
\hline 17 & Leadership & 0,06929 & 0,012382 \\
\hline 18 & Fairness & 0,06156 & 0,011001 \\
\hline 19 & Strategy & 0,04863 & 0,008690 \\
\hline 20 & $\begin{array}{l}\text { Knowledge } \\
\text { Management }\end{array}$ & 0,04607 & 0,008232 \\
\hline 21 & Ethics & 0,04417 & 0,007892 \\
\hline
\end{tabular}

(Source: Super Decision, processed by the researcher) 


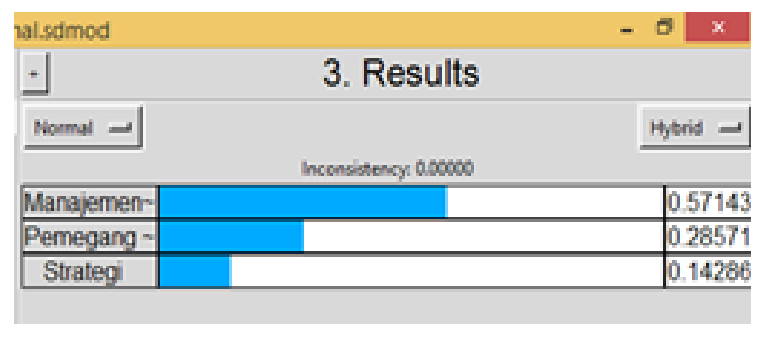

Figure 3 ANP Output between Clusters

The situation above has confirmed changes in the three following aspects: (1) The management of the company $(0,57143)$, according to the information from the experts, the policies that had been directed by the shareholders may be modified strongly to adjust in practice. It has been modified, but the directors have the strong possibilities to propose a revised version of strategy or target to the shareholders. In term of strategy implementation and formulation, the management of the company's role would be huge because they would be the one who had to deal with all kinds of business challenges of the company. This situation has put the management of the company to be more fluent about the detail of the company. (2) The shareholders $(0,28571)$, as the owner of the company also have some contributions as well in the business strategy formulation. The shareholders have the power to set the business target, to direct and generate the strategy, even to hire, or fire the directors. However, the real things require the practical solutions, which in this term is the management of the company would be more fluent, compared to the shareholders. This is the opinion of the experts (participants). (3) The Strategy $(0,14286)$ which is a product that was delivered by the management of the company and the shareholders to achieve the objectives of the company. Though the strategy has a very crucial role in term of directing a company, there are big chances for changing. The strategy could be revised to be relevant to the current situation. The final result of the business strategy formulation by the management of the company and the shareholders is the alternative priority alternative synthesis. The result would be shown in Figure 3. In addition, the result was released by the same software, Super Decisions.

Table 4 Description of Solutive Act of the Strategic Hierarchy and Impelementer Management Matrix

\begin{tabular}{|c|c|c|c|c|}
\hline \multicolumn{2}{|r|}{ Strategy Priority } & \multirow{2}{*}{ Limiting } & \multirow{2}{*}{ Solutive Explanation } & \multirow{2}{*}{$\begin{array}{l}\text { Management } \\
\text { Hierarchy }\end{array}$} \\
\hline No & Node & & & \\
\hline 1 & Differentiation Strategy & 0,163718 & Business development & Top \\
\hline 2 & Decision-making & 0,116377 & Precise, fast and accurate decision-making & Management \\
\hline 3 & Interpersonal & 0,091952 & $\begin{array}{l}\text { Good communication to have more conducive } \\
\text { working atmosphere }\end{array}$ & \\
\hline 4 & Finance & 0,090214 & Healthy cash flow & \\
\hline 5 & Costumer & 0,087602 & Generate the customers' satisfaction & \\
\hline 6 & Information & 0,064300 & $\begin{array}{l}\text { Sensitivity on business development, inside or } \\
\text { outside the company }\end{array}$ & \\
\hline 7 & Cost Leadership Strategy & 0,062910 & $\begin{array}{l}\text { Create the high-quality product with the lowest } \\
\text { possible cost }\end{array}$ & \\
\hline 8 & Learning and Growth & 0,050831 & $\begin{array}{l}\text { Capability of the company to be steady and to } \\
\text { innovate based on experience }\end{array}$ & $\begin{array}{c}\text { Middle } \\
\text { Management }\end{array}$ \\
\hline 9 & Internal Business Process & 0,047403 & Make sure the SOP is properly done for the business & \\
\hline 10 & Focus Strategy & 0,046001 & Focus on target achievement & \\
\hline 11 & Commitment & 0,035042 & Target achievement maximization & \\
\hline 12 & Accountability & 0,033513 & $\begin{array}{l}\text { Internal check and balance through effective } \\
\text { controlling }\end{array}$ & \\
\hline 13 & Transparency & 0,017141 & Be transparent to share information & \\
\hline 14 & Responsibility & 0,015115 & Consistent with all provisions related & \\
\hline 15 & Independency & 0,014962 & Run the business based on SOP & Low \\
\hline 16 & Competency & 0,014723 & The right competent operator & Management \\
\hline 17 & Leadership & 0,012382 & Leadership regeneration & \\
\hline 18 & Fairness & 0,011001 & Compensation based on competency and risk & \\
\hline 19 & Strategy & 0,008690 & $\begin{array}{l}\text { Product development, effective and efficient } \\
\text { business network development }\end{array}$ & \\
\hline 20 & Knowledge Management & 0,008232 & Scheduled training based on needs & \\
\hline 21 & Ethics & 0,007892 & Integrated employees & \\
\hline
\end{tabular}


Table 5 Group of Main Priorities of Strategic Hierarchy

\begin{tabular}{clcc}
\hline Priority & \multicolumn{1}{c}{ Node } & Limiting & Hierarchy \\
\hline$(1)$ & \multicolumn{1}{c}{$(2)$} & $(3)$ & $(4)$ \\
\hline 1 & Differentiation Strategic & 0,163718 & Strategic \\
2 & Decision-making & 0,116377 & \\
3 & Interpersonal & 0,091952 & \\
4 & Finance & 0,090214 & \\
5 & Costumer & 0,087602 & \\
6 & Information & 0,064300 & \\
7 & Cost Leadership Strategy & 0,062910 & \\
\hline 8 & Learning and Growth & 0,050831 & Tactical \\
9 & Internal Business Process & 0,047403 & \\
10 & Focus Strategy & 0,046001 & \\
11 & Commitment & 0,035042 & \\
12 & Accountability & 0,033513 & \\
13 & Transparency & 0,017141 & \\
14 & Responsibility & 0,015115 & \\
15 & Independency & 0,014962 & Operational \\
16 & Competency & 0,014723 & \\
17 & Leadership & 0,012382 & \\
18 & Fairness & 0,011001 & \\
19 & Strategy & 0,008690 & \\
20 & Knowledge Management & 0,008232 & \\
21 & Ethics & 0.007892 & \\
\hline & & & \\
\hline
\end{tabular}

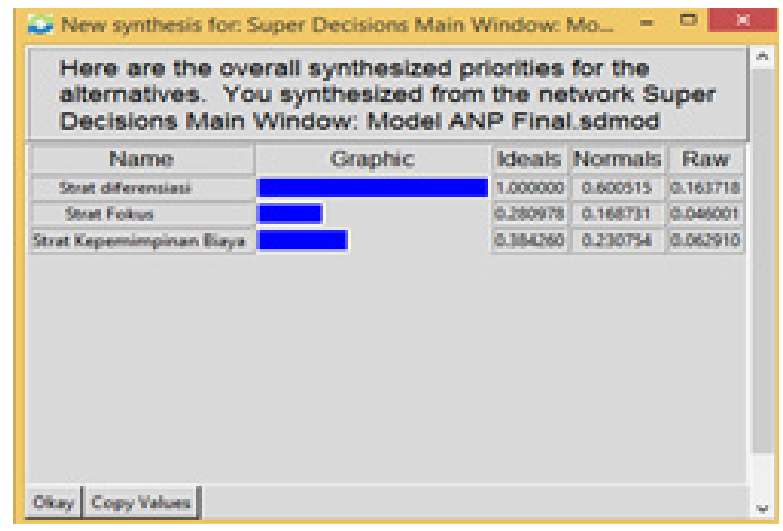

Figure 4 Synthesis Alternative ANP Output Strategy (Source: Super Decision, processed by researchers)

The strategy alternative selection is done by using the priority way, which means it chose the one that has the highest final score to become the main strategy. The output shows that the selected strategy alternative which is selected by priority is the differentiation strategy $(0,600515)$, cost leadership strategy $(0,230754)$ and focus strategy $(0,168731)$.

In the analysis of the whole output in the earlier discussion, the differentiation strategy, and the cost leadership strategy are considered as the strategic action that should be done by the company, and the focus strategy is categorized as the tactical step.

\section{CONCLUSIONS}

The research is done with the references review, in-depth interview with the experts and shareholders. The data is analyzed by the Super decisions software. Based on the research result, the researchers have come up with four conclusions. First, there are some roles of the shareholders inside the business strategy formulations in the company. The three roles based on priorities are pushing the accountability of the company, creating the commitment so that the target will be achieved maximally, and competency. 
The other roles of the shareholders are pushing the company's responsibility, and boosting the transparency, independency, fairness inside and outside the company, excellent leadership, good management, perfect strategy, fast and accurate, and ethic of the company. Second, the management of the company's role in the business strategy formulation, based on priorities are decision-taker on the right time, good interpersonal relationship, which would lead to the good atmosphere of the company, and their sensitivity to the information growth inside or outside of the company. Third, both shareholders and the management of the company share the same important roles in term of strategy formulation. Based on the output of pairwise comparison, between the shareholders, management of the company, and strategy clusters. It is revealed that the role of the management of the company is higher $(0,57143)$ compared to the shareholders $(0,28571)$. Fourth, there are some priority strategies that have been considered as the alternative to the final analysis. There are differentiation strategy $(0,600515)$, cost leadership strategy $(0,230754)$ and focus strategy $(0,168731)$. Differentiation strategy and cost leadership strategy are in the strategy hierarchy, while the focus strategy is in the tactical hierarchy.

Based on the result of the analysis and the conclusions, this research will imply four things. First, the highest priorities of the management of the company cluster are the decision-maker $(0,57143)$ and interpersonal $(0,28571)$, while information is the third priority $(0,14286)$. Based on this priority, the analysis can show that the management of the company plays an important role in decision-making term of the company. Thus, the whole stakeholders should have given the full support and wider space for the management to decide some business strategy without abandoning the monitoring, so the role of the management will be maximum. Second, the ANP priorities to the shareholder cluster's output show that the top priority is accountability. Respectively, the most urgent priority to the less urgent are accountability $(0,29934)$, commitment $(0,15628)$, competency $(0,07814)$, responsibility $(0,07680)$, independency $(0,07297)$, leadership (0,07162), fairness $(0,07162)$, transparency $(0,05765)$, strategy $(0,03955)$, management of the company $(0,03955)$, and ethic $(0,03648)$. Based on the information, it can be known that accountability is a very highlighted factor for the shareholders. That is why the decision-making role that has been given to the management of the company should be followed by good accountability so that interests of all parties would be accommodated leading the company to the higher level. Third, the result shows that the priorities are the customer $(0,36364)$, finance $(0,36364)$, internal business process $(0,18182)$, and learning and growth $(0,09091)$. The strategy that has been recommended for all the companies that are involved in this research is the customer orientation strategy. It means each company should be able to give the top priority to the customer satisfaction leading to the loyal customers, and at the end, it will gain new customers. Fourth, it is shown that the chosen strategy alternative based on priorities are differentiation strategy $(0,600515)$, cost leadership strategy $(0,230754)$, and focus strategy $(0,168731)$. This information is in line with the strategy optimization which is customer-oriented. To gain customers from various reach, the strategy that does not point to one market is necessary. Variation of the product is one thing that can be done.

Based on the earlier information of this research, and from the conclusions as well, three following suggestions can be proposed. First, regarding implementing the result of the research, it will require some socialization steps to all over the company, all departments and a kind of scheduled-evaluation. For instance, a three-monthly board of directors and board of commissioner meeting should be disseminated through internal email of the company to the whole division and department leaders. Second, email is by far the most effective communication media, so if there are questions, it will inform the board of directors and board of commissioner quickly. Third, after the results of the research have been socialized, further research will be required to break-down the solutive-steps offered by each management's hierarchy into each department of every company.

\section{REFERENCES}

Azis, I. J. (2003, November). Analytic Network Process with feedback influence: A new approach to impact study. In Paper for Seminar Organized by Department of Urban and Regional Planning, University of Illinois at Urbana-Campaign.

Bai, G. (2013). How do board size and occupational background of directors influence social performance in for-profit and non-profit organizations? Evidence from California hospitals. Journal of Business Ethics, 118(1), 171-187. doi: 10.1007/s10551-0121578-X

David, F. R. (2011). Strategic management - Concepts and cases. New York: Prentice Hall.

Edelman, L. F., Brush, C. G., Manolova, T. S., \& Greene, P. G. (2010). Minority nascent entrepreneurs. Journal of Small Business Management, 48(2), 174-196. doi: 10.1111/j.1540-627X.2010.00291.X

Kaplan, R. S., \& Norton, D. P. (1996). The balanced scorecard: Translating strategy into action. Massachusetts: Harvard Business School Press.

Millet-reyes, B., \& Zhao, R. (2010). A comparison between one-tier and two-tier board structures in France. Journal of International Financial Management \& Accounting, 21(3), 279-310

Nickols, F. (2000). Strategy is... alot of things. Distance Consulting, 297-311.

Ntim, C. G., Opong, K. K., \& Danbolt, J. (2012). The relative value relevance of shareholder versus stakeholder corporate governance disclosure policy reforms in South Africa. Corporate Governance, 20(1), 84105. doi: 10.1111/j.1467-8683.2011.00891.x 
Porter, M. E. (1990). New global strategies for competitive advantage. Planning Review, 18(3), 4-14. doi: $10.1108 / \mathrm{eb} 054287$

Price, R., Roman, F. J., \& Rountree, B. (2011). The impact of governance reform on performance and transparency. Journal of Financial Economics, 99(1), 76-96. doi: 10.1016/j.jfineco.2010.08.005

Saaty, T. L. (2003). Decision-making with the AHP: Why is the principal eigenvector necessary. European Journal of Operational Research, 145(1), 85-91. doi: 10.1016/S0377-2217(02)00227-8

Saaty, T. L. (2008). Decision making with the analytic hierarchy process. International Journal of Services Sciences, 1(1), 83. doi: 10.1504/IJSSCI.2008.017590

Siregar, S. V., \& Bachtiar, Y. (2010). Corporate social reporting: Empirical evidence from Indonesia stock exchange. International Journal of Islamic and Middle Eastern Finance and Management, 3(3), 241-252. doi: 10.1108/17538391011072435

Wheelen, T., \& Hunger, D. (2011). Strategic management and business policy - toward global sustainability. New York: Prentice Hall 